\title{
PANCURONIUM AND RENAL PERFUSION: A COMPARISON OF NEUROMUSCULAR BLOCKING AGENTS
}

\author{
KenNeth M. Leighton, M.B., F.R.C.P.(C) ${ }^{\circ}$, BEverly Koth, AND \\ Caroline Bruce, (hons.) B.SC.( ST. and.)
}

General Anaesthetic Agents, and other drugs employed in modern anaesthesia, produce effects upon organs and tissues other than those for which they are specifically employed. Anaesthetics such as halothane, for example, whose primary target organ is the central nervous system, act with marked effect upon the cardiovascular system. The same is true for other agents which are used in the conduct of general anaesthesia. Narcotics, which are employed for their action upon the central nervous system, have far-reaching effects upon many organs and tissues, including the gastrointestinal system and the kidney. ${ }^{1-3}$

The kidney, indeed, is particularly vulnerable to the actions of anaesthetic agents and other drugs employed in anaesthesia, since a relatively large proportion of cardiac output is delivered to the organ and since the filtering and concentrating mechanisms of the kidney promote intimate and, perhaps, prolonged exposure to potent and even toxic anaesthetic agents and their metabolites. In addition, since so many agents (directly and indirectly) affect the cardiovascular system, both centrally and peripherally, the kidney is again at hazard because its function is dependent upon its blood supply, and the internal distribution of its perfusion. ${ }^{4}$

Changes in total renal blood flow, in renal artery pressure and in glomerular blood flow have been shown to produce marked changes in renal function. ${ }^{5}$ Outar cortical nephrons are "salt-losing nephrons" and juxtamedullary or inner cortical nephrons are salt retainers. ${ }^{6}$ It is clear, then, that an alteration in cortical perfusion can change the general characteristics of the manner in which the glomerular filtrate is handled and the ultimate characteristics of the final product, urine. Such changes in cortical perfusion have been demonstrated and, indeed, have been shown to follow such an extrarenal event as systemic hypotension.?

The depolarizing neuromuscular blocking agent, succinylcholine, has been shown to lower total renal blood flow, albeit transiently. ${ }^{8}$ This fall in flow is accompanied by some fall in arterial blood pressure, although this latter is not necessarily below levels at which renal blood flow is normally held constant by means of the intrinsic autoregulatory mechanisms with which the kidney is endowed.

Following the administration of d-tubocurare, systemic arterial hypotension is frequently observed. This hypotension has been attributed in part to histamine release and in part to autonomic ganglionic blockade. "Whatever the mechanism,

-Assistant Professor, Departments of Anaesthesia and Pharmacology, Faculty of Medicine, The University of British Columbia, Vancouver 8, B.C.

This work was supported by a grant in aid of research awarded by the British Columbia Heart Foundation.

Canad. Anaesth. Soc. J., vol. 21, no. 2, March 1974 
such a change in circulatory dynamics may be anticipated to produce some alteration in renal blood flow.

Gallamine triethiodide frequently, through its vagolytic action, is followed by tachycardia and, occasionally, by some increase in arterial blood pressure. It is possible that these effects might be associated with changes in renal blood flow. In addition, this agent appears to depend upon renal excretion for the termination of its neuromuscular blocking activity, since it is excreted, unchanged, in urine. ${ }^{9}$ Thus, when renal perfusion and glomerular filtration may be altered by anaesthetic and by other drugs, the handling of this neuromuscular blocking agent may obviously be affected.

Pancuronium is a steroid neuromuscular blocking agent comparatively recently introduced into general anaesthetic practice in North America. ${ }^{10}$ This agent appears to have few cardiovascular effects other than the production of a mild tachycardia and sometimes a mild rise in arterial blood pressure. ${ }^{11.12}$ Even so minor a generalized cardiovascular effect might, however, be accompanied by changes in the perfusion of individual organs.

Thus it appears that the commonly employed neuromuscular blocking agents have some cardiovascular actions and possess at least the potential for changing renal perfusion and hence renal function.

Accordingly, it was decided to investigate the effects of all these agents upon total renal blood flow. Particular attention was to be focussed upon the newest agent, pancuronium, since it appears to have the least general cardiovascular effects of all such agents so far studied.

Since general anaesthetics influence the cardiovascular system and thus affect renal blood flow, both directly and indirectly, it was decided to compare each of the four neuromuscular blocking agents and their effects upon renal blood flow in the presence of halothane, methoxyflurane, nitrous oxide and a narcotic (alphaprodine).

\section{Method}

Forty-seven experiments were performed on eight mongrel dogs. Chronic preparations were employed. The animals were prepared by placing a Doppler ultrasonic flow probe (Parks Electronics, Beaverton, Oregon) around the left renal artery through a flank incision, employing the extraperitoneal approach. A similar flow probe was placed around the ascending aorta through a thoracotomy performed at the same time. This permitted observation of changes in total renal blood flow and in cardiac output. Leads from these probes were exteriorized at the back of the neck.

The animals were permitted to recover from this surgery for not less than one week. They were then anaesthetized with thiopentone $(20 \mathrm{mg} / \mathrm{kg})$, intubated with a tracheal tube and ventilated with a Palmer pump. Anaesthesia was maintained with halothane and oxygen, methoxyflurane and oxygen, alphaprodine ( $24 \mathrm{mg}$ intravenously and $12 \mathrm{mg}$ increments thereafter) and oxygen and nitrous oxide and oxygen. Alphaprodine increments were administered when a rising arterial pressure, tachycardia or limb twitching indicated light anaesthesia. 
One or other femoral artery was cannulated in order to permit arterial pressure measurement and blood gas sampling. Ventilation was maintained so that $\mathrm{PaO}_{2}$ was greater than $100 \mathrm{~mm} \mathrm{Hg}, \mathrm{PaCO}_{2}$ between 30 and $40 \mathrm{~mm} \mathrm{Hg}$ and $\mathrm{pH}$ between 7.35 and 7.46. The animals were placed on a warming blanket and rectal temperatures were maintained between $39^{\circ}$ and $40^{\circ} \mathrm{C}$.

Intravenous infusions of 5 per cent dextrose in lactated Ringer's solution ran throughout the experiments. The volume of fluid administered varied, depending upon the duration of the experiment. The rate of administration was approximately $75 \mathrm{ml}$ per hour.

When stable conditions (arterial pressure, blood gas readings and blood flows) were obtained, succinylcholine $4 \mathrm{mg} / \mathrm{kg}$ was administered. At separate experiments, $0.5 \mathrm{mg} / \mathrm{kg}$ d-tubocurare or $1.0 \mathrm{mg} / \mathrm{kg}$ gallamine triethiodide were given. The dose employed in the case of pancuronium was $0.1 \mathrm{mg} / \mathrm{kg}$.

These neuromuscular blocking agents were administered, in turn, to animals anaesthetized with halothane, methoxyflurane, alphaprodine and nitrous oxide, as has been described above.

Succinylcholine was employed in the dose of $4 \mathrm{mg} / \mathrm{kg}$ because this is the dose employed by earlier investigators of some of the cardiovascular effects of this drug. ${ }^{13} 1.0 \mathrm{mg} / \mathrm{kg}$ was also administered in several experiments, since this more accurately approaches the dose employed in clinical practice.

\section{Results}

The effect of succinylcholine upon renal blood flow has already been reported elsewhere. ${ }^{8}$ Briefly, there is a marked but transient fall in renal blood flow and a more minor fall in arterial pressure. The fall in renal flow occurs when arterial pressure is greater than the $70 \mathrm{~mm} \mathrm{Hg}$ mean which is generally held to be the lower limit for autoregulation of renal blood flow. Following these falls there is a compensatory overshoot in both renal blood flow and arterial pressure. No difference in this response was observed with any of the anaesthetic agents employed in this series (Figure 1).

When d-tubocurare was studied, a fall in arterial pressure, cardiac output and renal blood flow were observed. This effect was of considerably longer duration than that shown by succinylcholine. Renal blood flow took up to five minutes to return to its pristine level following the administration of this agent. None of the general anaesthetic techniques altered this response (Figure 2).

Gallamine routinely produced an increase in heart rate. This increase, as might be anticipated, was less marked in the presence of a pre-existing tachycardia than in those dogs in whom there was bradycardia. Increases in arterial blood pressure were frequent, but inconsistent. In some instances the rise was marked (more than $30 \mathrm{~mm} \mathrm{Hg}$ increase). Renal blood flow alterations were, however, slight and inconsistent. Very minor increases in flow were occasionally observed. No difference in these responses to gallamine were noted when the general anaesthetic agents and techniques were changed in accordance with the experimental protocol (Figure 3).

Pancuronium gave rise to the least change in the cardiovascular system in 


\section{methoxyflurane}

co

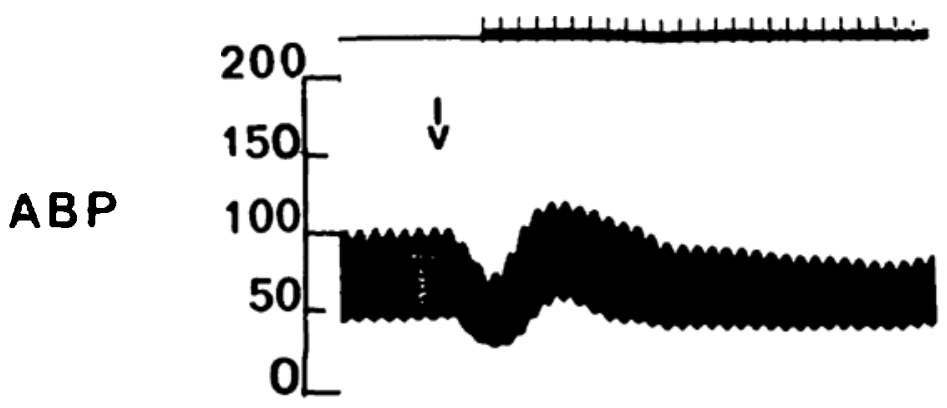

RB F

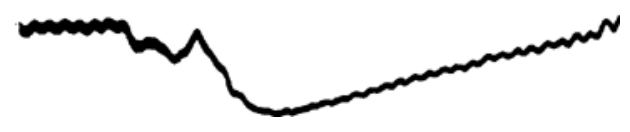

\section{Img/kg succinylcholine}

FIGURE 1. The influence of succinylcholine on arterial blood pressure (APB) and renal blood flow (RBF) during methoxyflurane anaesthesia. No difference in this response was observed with any of the anaesthetic agents employed in this series.

general and the renal blood flow in particular. Occasionally a very minor increase in heart rate was observed. Arterial blood pressure and renal blood flow altered neither consistently nor significantly (Figure 4).

\section{Discussion}

This study appears to demonstrate that pancuronium has no effect upon total renal blood flow and hence it is unlikely to affect the distribution of renal perfusion. Of all the other neuromuscular blocking agents heretofore employed, prior to the introduction of pancuronium, only gallamine appears to have so little 


\section{alphaprodine}

Co
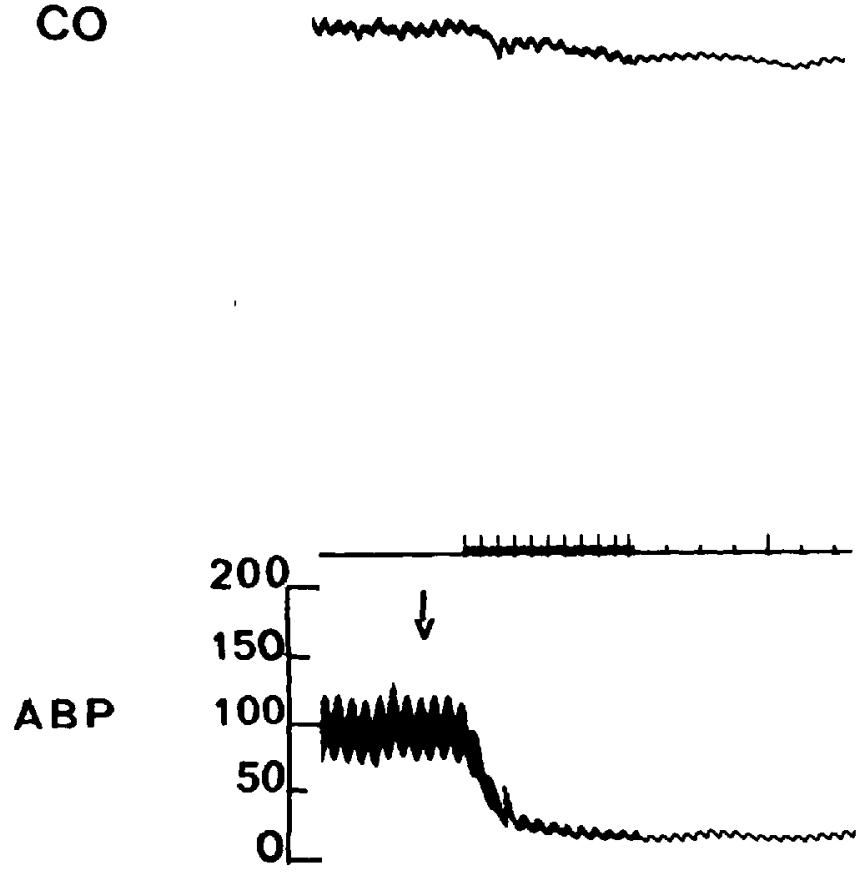

\section{RBF}

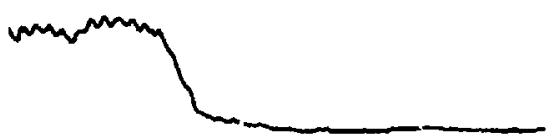

\section{$.5 \mathrm{mg} / \mathrm{kg} \mathrm{d}$-tubocurare}

Figure 2. Effect of d-tubocurare on arterial blood pressure (APB) and renal blood flow (RBF).

effect upon renal blood flow. Since gallamine, however, has quite marked cardiovascular actions which may render its employment undesirable in general and since its pathway for excretion is almost exclusively renal, ${ }^{14}$ its use may be contraindicated in the presence of severe renal impairment. ${ }^{15}$

It has been shown that pancuronium has a prolonged action in the cat when all kidney function has been removed. ${ }^{16}$ Similarly, in man, a prolonged pancuronium effect has been observed in the presence of severe renal failure. ${ }^{17}$ Since it is known that this agent is excreted at least partially by the kidney, ${ }^{18,10}$ these findings are not surprising.

MacIntyre and Gain, however, have reported that pancuronium employed for neuromuscular blockade in patients with severe renal dysfunction was not accompanied by prolonged curarization nor by re-curarisation ${ }^{20}$ so that it is clear 
co

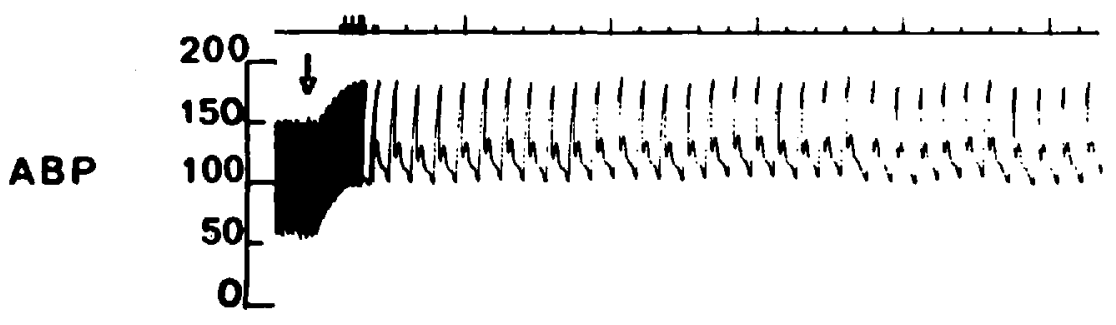

RBF

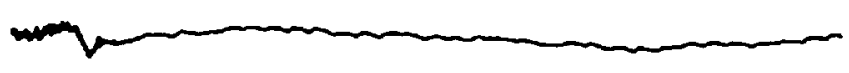

\section{$1 \mathrm{mg} / \mathrm{kg}$ gallamine}

Figure 3. Effect of gallamine on arterial blood pressure (ABP) and renal blood flow (RBF).

co

$$
\text { halothane }
$$

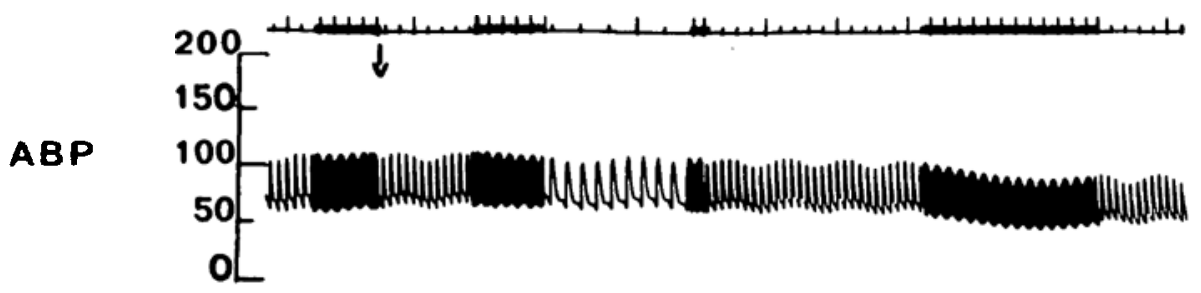

RB F

\section{$.1 \mathrm{mg} / \mathrm{kg}$ pancuronium}

FIcure 4. Effect of pancuronium on arterial blood pressure (ABP) and renal blood flow (RBF). 
that the prolonged action reported by other authors in these circumstances is neither constant nor inevitable.

From our studies, therefore, and from those cited above one may conclude that pancuronium has less effect upon renal blood flow than either succinylcholine or d-tubocurare and that the other cardiovascular actions of gallamine, together with its obligatory renal pathway of excretion, make pancuronium potentially the safest agent in some conditions of cardiovascular instability and in the presence of disturbed renal function.

\section{SUMMary}

Neuromuscular blocking agents in general have moderate to marked cardiovascular effects. Pancuronium, a recently introduced neuromuscular blocker, appears to have effects which are stimulatory, rather than inhibitory, upon the cardiovascular system and these effects are, in general, but slight. A study of pancuronium, succinylcholine, d-tubocurare and gallamine in the presence of halothane, methoxyflurane and alphaprodine suggests that the effect of pancuronium upon renal blood flow is negligible and that this is not the case for succinylcholine or d-tubocurare. Gallamine also has minimal effects upon renal blood flow, but has its own well-documented problems in the presence of severe renal dysfunction.

\section{RÉSUMÉ}

En général, les relaxants musculaires exercent des effets cardio-vasculaires d'intensité variable. Dans cette optique, le Pancuronium, nouveau-venu dans cette gamme, semble posséder des propriétés stimulantes plutôt que dépressives mais en général les effets en sont minimes.

Notre étude a porté sur l'influence du Pancuronium sur le débit sanguin rénal en présence de Halothane, de Méthoxyflurane et d'Alphaprodine.

Comme celle de la Gallamine, l'influence du Pancuronium s'avère négligeable contrairement à l'action exercée par la Succinylcholine et la d-tubocurarine.

On se rappellera cependant les effets bien connus de la Gallamine en présence d'insuffisance rénale.

\section{REFERENCES}

1. Goodman, L.S. \& Gilman, A. The pharmacological basis of therapeutics. 4th ed. Toronto \& London: Macmillan (1970).

2. Deutsch, S., Bastron, R.D., Pierce, E.C., Sr., et al. The effects of anaesthesia with thiopentone, nitrous oxide, narcotics and neuromuscular blocking drugs on renal function in normal man. Brit. J. Anaesth. 41:698 (1964).

3. Grarman, N.J. \& Condouris, G.A. The antidiuretic action of morphine and some of its analogues. Arch. Int. Pharmacodyn. 97: 28 (1954).

4. Thurau, K. Renal haemodynamics. Amer. J. Med. 36: 698 (1964).

5. Hatch, R.D. \& Johnson, J.G. Intrarenal blood flow. Ann. Rev. Med. 20: 395 (1969).

6. BARger, A.C. \& HerD, J.A. The renal circulation. New Eng. J. Med. 284: 483 (1971).

7. Hollenberg, N.K., Efstein, M., Rosen, S.M., Basch, R.I., Oken, D.E., \& Merrill, J.P. Acute oliguric renal failure in man: evidence for preferential renal cortical ischaemia. Medicine (Balt.) 47: 455 (1968).

8. Leighton, Kenneth Macrae. Studies on the effect of succinylcholine upon the circulation of the anaesthetized dog. Canad. Anaesth. Soc. J. 18: 100 (1971). 
9. Wylie, W.D. \& Churchill-Davidson, H.C. A practice of anaesthesia. 3rd ed. London: Lloyd-Luke (Medical Books) Ltd. (1972).

10. Katz, R.L. Clinical neuromuscular pharmacology of pancuronium. Anesthesiol. 34: 550 (1971).

11. MCDowell, S.A. \& ClaRke, R.S.J. A clinical comparison of pancuronium with d-tubocurarine. Anaesthesia 24: 581 (1969).

12. LoH, L. The cardiovascular effects of pancuronium in man. Anaesthesia 23: 356 (1970).

13. Adams, A.K. \& Hall, L.W. An experimental study of the actions of suxamethonium on the circulatory system. Brit. J. Anaesth. 34: 445 (1962).

14. Chagas, C. The fate of curare during curarisation. In CIBA Fdn. Study Group 12, Curare and Curare-like Agents, edited by A.V.S. DERueck. Lonclon: Jano A. Churchill (1962).

15. Churchill-Davidson, H.C., Way, W.L., \& DeJonc, R.H. The muscle relaxants and renal excretion. Anesthesiol. 28: 540 (1967).

16. Adler, L. \& Pilon, R.N. Duration of neuromuscular blockade in anephric cats. Presented at American Society of Anaesthesiologists Meeting, Boston (1972).

17. Miller, R.D., Stevens, W.C., \& WAY, W.L. The effect of renal failure and hyperkalaemia on the duration of pancuronium neuromuscular blockade in man. Anesth. Analg. (Cleveland) 52: 661 (1973).

18. Speirs, I. \& Sims, A.W. The placental transfer of pancuronium bromide. Brit. J. Anaesth. 44: 370 (1972).

19. Strunin, L., Strunin, J.M., Layton, J., Sim, A.W., \& Simpson, B.R. Metabolism of ${ }^{14} \mathrm{C}$-pancuronium bromide by the isolated perfused canine liver. Brit. J. Anaesth. 44: 624 (1972).

20. MAcINTYRE, J.W.R. \& GAIN, E.A. Initial experience during the clinical use of pancuronium bromide. Anesth. Analg. (Cleveland) 50: 813 (1971). 